\title{
Clinical Events Start Date Time
}

National Cancer Institute

\section{Source}

National Cancer Institute. Clinical Events Start Date Time. NCI Thesaurus. Code C87857.

The date and time of the beginning of a clinical event. 